\title{
Driving out the Undeserving Poor
}

\author{
Jan Breman
}

At the beginning of the 21st century, historical research about the toil, troubles and achievements of workers and labor movements is undergoing an exciting transition to a truly Global Labor History. ${ }^{1}$

\section{1 \\ Dealing With Vulnerability in the Pre-capitalist Past}

Peasant life based on a simple mode of production dominated the pre-capitalist history of a large part of humankind for millennia. Stone-age economics revolving around hunting and gathering, although continuously practiced in many zones of our planet, were steadily surpassed by more sedentary forms of work and living. Lack of control over natural resources did not allow for much more than precarious survival, but the condition of poverty that prevailed was a shared experience. Arrangements for production and livelihood took place in small-scale communities, and the majority of the world's population lived in households that remained embedded in these primary anchor points of ancient civilizations. With a surplus siphoned off at the behest of supra-local lords engaged in early state formation, the peasantry produced for its own frugal subsistence. A communitarian ethos saw to it that they helped each other out in times of hardship; this redistribution was facilitated by the still cashless character of the localized economy. With an increase in output-the result of technological advancements that led to better control over the forces of nature-differentiation in the ownership of means of production set in and gave rise to a more varied life style, also at the local level. This was the beginning of a social divide, which according to Alexis de Tocqueville arose in a new stage of settled - that is, domesticated-agriculture following slash-and-burn cultivation. In his first Memoir on Pauperism (1834), he argued that:

from the moment that landed property was recognized and men had converted the vast forests in fertile land and rich pastures, from this

1 Marcel van der Linden, Workers of the World; Essays Toward a Global Labor History (Leiden/ Boston, 2008), 1. 
moment, individuals arose which accumulated more land than they requited to feed themselves and so perpetuated property in the hands of their progeny. ${ }^{2}$

Although the peasantry became more stratified, a common fund remained in place to deal with periods of collective adversity caused by the failure of harvests. While coping with calamities such as famine, war, or plague was all but impossible on a communal basis, the usual practice was to assume joint responsibility for individualized instances of indigence, and to take care of vulnerable households that were temporarily or indefinitely unable to provide for their livelihood. In these agrarian and still cashless economies, deserving cases for entitlement to rations handed out in kind ran the gamut from illness to old age and other forms of disability. Underlying such support was a binding code of reciprocity, which enabled people in dire straits to fulfil their subsistence needs. Redistributive mechanisms used to be endorsed by religious tenets advocating charity as a pious duty expressed in the collection of zakat under Islamic law or the tithe in the world of Christianity. Institutionalized in the Poor Laws throughout Europe from the Late Middle Ages onward, the prime recipients of relief were members of the local community. It is important to add that for the provision of communal care it was not only the non-working poor who qualified, but also people out of work and income at the low tide of the agrarian cycle. To keep them alive was also in the best interests of the nonpoor, who at the peak of agricultural activity might need those idle hands laid off in reserve. It was a situation in which labor power used to be scarcer than land, a large amount of which still remained uncultivated and classified for that reason as an open resource. Landowners needed to protect themselves in such circumstances against the shortage of workers by keeping them attached in bondage. ${ }^{3}$

To prevent or at least slow down an unwelcome trend toward progressive dispossession, many peasant societies were familiar with the custom of the commons, which implied open access to resources jointly held nearby, such as waste land or water, to people acknowledged as shareholding members of the same rural locality. A periodic redistribution of the cultivated land, as for instance in the traditional Russian mir or among native tribes in South America, was a more rigorous way to pre-empt progressive differentiation in property,

2 Alexis de Tocqueville, Alexis de Tocqueville's Memoir on Pauperism, trans. Seymour Drescher (London, 1997), 19, http://www.civitas.org.uk/pdf/Tocqueville_rr2.pdf.

3 Herman Jeremias Nieboer, Slavery as an Industrial System: Ethnological Researches (The Hague, 1910). 
power, and status. Were such customary forces that pressed for some modicum of compulsory redistribution a feature of all peasant societies? It seems more likely, as Tocqueville surmised, that a large part of humankind used to or came to live and work in societies marked by more or less inequality in all walks of life. In different parts of the world, varieties of feudalism had eroded the free disposal of gains from peasant holdings while silencing the voice of the victimized dispossessed. With large tracts of waste land still lying unproductive, labor was much in demand and had to be appropriated by extra-economic force. Agrestic serfs were at the beck and call of landlords, who attached landless households to their domain in a relationship of patronage and exploitation. Even then, while a set of notables engaged in surplus extraction and imposed their elevated ranking as a gentry in the maximization of power and status, the moral imperative of togetherness in a frame of proximity and familiarity prescribed that the patrons felt bound to allot a minor part of their proceeds, which allowed them a carefree existence and to take care of their clients who lacked the bare essentials required for survival. ${ }^{4}$

For the sake of keeping social cohesion intact, as well as justified from all sides, some form of entitlement had to be apportioned to the hapless needful bereft of the ability to stock up and stay alive independently. Thus, deprivation and accumulation did not become separated dynamics of adversity and prosperity, but instead remained intertwined in a corporate circuit of calibrated give and take. It was essentially an attempt to safeguard the inclusion of all stakeholders who could rightfully claim to belong to the community. Their interdependence rested on a face-to-face relationship, and was facilitated by an exchange of goods and services in kind rather than in cash. Consolidation of the trend toward unequal distribution was made conditional on granting the right to the inclusion of households lagging behind in the generation of surplus due to mishaps beyond their will or control. Of major significance was a clause in the customary social contract that acknowledged the claim for relief when out of work. Facing bouts of unemployability in the erratic agrarian cycle-leading to a livelihood deficit that could not be bridged by savings set aside - was met by support from the common fund.

However small scale in nature the communal membership may have been, outsiders were identified who remained excluded from whatever transfers

4 Jan Breman, Patronage and Exploitation: Changing Agrarian Relations in South Gujarat, India (Berkeley, 1974). 
took place at the local level. These were able-bodied people who either did not prefer to or did not manage to find admittance as fully-fledged members of a community in a relationship meant to be reciprocal. Many of those effectively excluded were victims of adversities that drove them to cut loose from wherever their origin had been. However, there were also people who, in order to escape being tied down in bondage, opted to remain footloose and did not want to settle down indefinitely. Habituated to wander around sourcing whatever occasional reprieve that happened to come their way, they turned up at weekly markets, annual fairs, and religious festivals to beg for alms, to offer their services as bards, conjurers, quacks, tinkers, fortune tellers, or tricksters, but also as ordinary workers willing to do a fair day's labor in or outside of agriculture. Their movement followed the rhythm of the seasons and they traveled around in search of any makeshift employment. This was a contingent of wage hunters and gatherers remaining on the margins of the localized economy, who peddled whatever they could lay their hands on or just chose to stay put waiting for a windfall to come their way and otherwise resorted to petty pilfering, They made off when their presence was no longer required, or were chased away when inhabitants of the locality turned against them. Blamed for shirking and loitering, these drifters found no access to mainstream society because of their wayward, abrasive, and shady character. In this stigmatized view, they were not torn loose from their social origin due to some misfortune, but had opted for a life of vagrancy. It is a portrait that takes sedentarism for granted and is apt to treat a taste for wandering - such as practiced by nomads, transporters, and other kinds of itinerant labor-with dismay and suspicion. The norm was settlement, and the acceptance of bondage in one form or the other. Those who remained footloose and opted for that unsettled way of life stood accused of escaping from social dependency and control.

Society was ordered in hierarchies that were unified by paternalism. Every man had his place, his function and his master in this scheme of things. There was no room for the vagrant: he was "masterless," and thus had broken away from the established order. He was idle, too, and thus not performing a useful function in the Common Weal. ${ }^{5}$

Such people were held in disrepute for having absconded from a regular existence; the label attached to them was that of the "undeserving poor." As long as they remained small in number, this "parasitic" residuum did not really pose

5 A.L. Beier, "Vagrants and the Social Order in Elizabethan England," Past \& Present 64 (August 1974): 3-29, here: 27 . 
a danger to the established order. Nevertheless, their floating around constituted a nuisance difficult to tolerate, since this good-for-nothing lot adroitly refused to bow down in docile subservience. Such was expected to be the habitus befitting the people without means who were rewarded for being willing to demonstrate their subaltern state: Because the incidental support the "deserving poor" were entitled to when confronted with adversity had to be accepted with gratitude, deference, and a show of allegiance. Another understanding of gestures of beneficence was that these prevented the recipients from stoking unrest and resorting to illegally appropriating what they were denied. Suspected of attempting to resist their commodification as a dispossessed underclass, itinerant people may have preferred a life of vagrancy rather than settling down in dependency or even servitude. All said and done, the divide between insiders eligible for communal relief and outsiders cut off from the local dole was not a hard and fast one but ranged over a continuum of restrictiveness to leniency, which used to be practiced in an arbitrary fashion, either mercilessly withheld or on the spur of the moment generously granted.

In the course of time, the linkage between the small-scale community and the outside world did increase. A decisive feature in the enlargement of scale was the loss of autonomy to settle matters and issues at the local level. This mandate tended to become usurped from seats of power higher up, and was made manifest in the downward imposition of administrative and political authority. Although the peasant community never had the self-sufficiency ascribed to it in an image which portrayed the village as autarkic-a closed system of production for consumption - there is no lack of evidence that with growing control over the resource base, goods and services came to be exchanged in widening networks of circulation. Domination and interference from outside over the local order, and infrastructural development with improved means of transport, allowed for trade routes to be established over longer distances than before. Agriculture still dictated life and work, and peasant society remained intact, although restructured into greater complexity. In addition to a growing division of labor and a lengthening of the chain of dependency, the outcome was a more differentiated economic-cum-social fabric marked by starker contrasts separating a local elite equipped with a disproportionate share of the means of production, from a sizable segment at the bottom made more dispossessed. The trend toward marketization meant not only that an increasing part of the output realized left the locality, but also that commodities and services previously unknown became available to those who could afford them. The inevitable result was a divergence class-wise in lifestyle, and a growing conflict of interests between winners and losers. The surge in 
commerce was accompanied by monetization, ultimately leading to a drastic change in the relations of production. It was a shift that found expression both in more pronounced swings in the demand for labor due to increased seasonality, and the replacement of payment in kind for labor rendered in cash. The proximity and familiarity that were the hallmarks of the peasant locality broke down to make way for a contractual distancing between the segments that had been tied to each other from generation to generation in a setting of complementarity and reciprocity.

One of the consequences of the loss of cohesion that kept the households in the small-scale community connected to each other, was a rapid increase in the number of people cut loose from wherever they belonged in terms of work and livelihood. From the sixteenth to the nineteenth century, this denigrated contingent, for a variety of reasons unsettled from their roots and habitat, increased in many parts of the world to a much larger footloose army than had existed previously. Again, a substantial contingent among them may have taken to the road in order to shy away from becoming entrapped as a sedentarized commodity, tied down in debt bondage. They joined the ranks of the multi-class riffraff that Karl Marx identified as the Lumpenproletariat, which in his all too scornful imagery was prone to criminality.

Alongside decayed roués with dubious means of subsistence and of dubious origin, alongside ruined and adventurous off shoots of the bourgeoisie, were vagabonds, discharged soldiers, discharged jailbirds, escaped galley slaves, swindlers, mountebanks, lazzaroni [homeless idlers], pickpockets, tricksters, gamblers, maquereaux [pimps], brothel keepers, porters, literati, organ grinders, rag-pickers, knife grinders, tinkers, beggars - in short the whole indefinite, disintegrated mass, thrown hither and thither, which the French call la bohème. ${ }^{6}$

Commitments of mutuality that used to bond households together no longer matched - or were even antagonistic to-concerns resulting from differential involvement in networks of exchange that reached beyond local leverage. Systems of poor relief, as they had operated in the past, came under pressure; the consequence of a spiraling clash of interests between dominant stakeholders engaged in a strategy of accumulation while the dominated ones were forced to make do with the wherewithal left to them. The increased vulnerability of subordinated households was compounded by the loss of bargaining power

6 Karl Marx, "The Eighteenth Brumaire of Louis Bonaparte (1851-52)," Karl Marx/Frederick Engels Collected Works (MECW) 11 (1976): 99-197, here: 149 . 
they had earlier enjoyed in a localized frame. Intruding market forces from higher up were fortified by a more encompassing and effective span of control, which required the exercise of jurisdiction within a much wider setting.

\section{Capitalism in the Countryside}

The dissolution of communal coalescence in the agrarian-rural order preceding the capitalist one, has first and foremost to be understood as heralding changes in the relations of production caused by the advancement of the new mode of accumulation facilitated by new storage and transport techniques. What had gone on before, patterned and institutionalized in vast diversity, was not immediately and contemporaneously obliterated, but lingered on, also in economic zones that were the first to yield to the spreading march of capitalism. The shift that found its impetus in a trend toward the commodification of land and labor was first described and analyzed for different parts of Europe. Karl Polányi aptly phrased the gist of the new deal that came about:

No relief any longer for the able-bodied unemployed, no minimum wages either, not a safeguarding of the right to live. Labor should be dealt with as that which it was, a commodity which must find its price in the market. ${ }^{7}$

His succinct statement indicates how the balance between capital and labor became more tilted, prioritizing the interests of the former and victimizing those of the latter. Much of the literature on the subject consists of accounts specifying what was going on in different parts of Great Britain. The transformation that materialized gave rise to a major increase in labor mobility, and may already have taken shape in the agrarian-rural landscape before catching on in other sectors mainly concentrated in the, until then, relatively small urban economy.

In a rationalization drive from the second half of the eighteenth century onward, British rural magnates introduced new farming technology and crop rotation. They added to their property land that had been part of the village commons, forcing enclosure either in private deals or legislated by a parliament in which landlords called the shots. What used to be open fields, subdivided into holdings that the agrarian poor had cultivated for their mainstay, were now fenced off and managed by the owners of large estates. As a

7 Karl Polányi, The Great Transformation. The Political and Economic Origins of Our Times (Boston, 1944), 117. 
consequence of the enclosure movement, the yield of land was made more productive and commercially more profitable. The spirit of accumulation was well served by the concentration of ownership into fewer hands; those of the rural gentry and a peasant segment consisting of well-to-do freeholders mixed with more powerful tenant farmers. At the polar opposite end of the hierarchy, a very sizable class of petty cultivators lost their holdings to join the ranks of the landless proletariat and make a mean living as waged workers in a tight and seasonally fluctuating labor market. The congestion that built up at the bottom of the rural-agrarian economy was a major cause of rising destitution.

The "Speenhamland Ordinance," passed at the end of the eighteenth century, was a regional regulation resorted to in South England in an attempt to redress rural distress caused by soaring grain prices. Laboring households unable to afford their regular food ration received a supplement to make up their budget deficit; a subsidy that was charged to the landowners of the parish. This add-on, dependent on the price of bread and the size of the household, was granted to allay fears of growing discontent among the rural proletariat, and was made when the French Revolution was in full swing. It enabled landowners to keep the reservoir of cheap labor intact, which could be tapped whenever required. Although the subsidy did not last long - the cash supplement was withdrawn again when the Napoleonic wars were over and the threat of social revolt subsided - it must have whetted the appetite of the underclass for a guaranteed minimum income with which to satisfy their basic needs throughout the annual cycle. Once the threat of revolution started to fade away in the early nineteenth century, the rural poor in England also were back to being exposed to the vagaries of an overcrowded labor market.

Could communal support as provided under the Poor Laws at least keep the immiseration of a huge and expanding underclass within bounds? This was this question that, quite unforeseen, came to preoccupy Alexis de Tocqueville. In an essay that for a long time remained fairly unnoticed, the French aristocrat gave vent to his views on pauperism and how to deal with it. Like many of his contemporaries around the mid-nineteenth century, the political philosopher expressed his belief that public welfare demoralized the laboring poor, rather than alleviating their unfortunate plight. In his considered opinion, it debased them to a condition of permanent inferiority. On his return from the famed trip made to the New World, he paid a short and private visit to England in 1833 . The estate owner with whom he stayed in south England was a peer, like him a landlord who also acted as a justice of the peace. At his invitation, Tocqueville attended court sessions in which suits were brought by the poor against the parish or the other way round. He astutely observed that the ire felt by the payers of the poor rate was not only directed against the indolent underclass, but also 
extended to the local overseers empowered to tax the non-poor of the parish for the levy they were obliged to contribute, and who made decisions on granting or rejecting claims for benefit made by impoverished inhabitants. Tocqueville contrarily argued that:

Any measure which establishes legal charity on a permanent basis and gives it an administrative form thereby creates an idle and lazy class, living at the expense of the industrial and working class. ${ }^{8}$

The voices clamoring for amendments to the Poor Laws had already prevailed when Tocqueville was still busy writing up the findings of his first tour. The revision parliament debated and in 1834 enacted reduced the cost of looking after the poor by taking away the right to public relief when no local employment could be found. The benefit was forthwith withheld from the poor of working age and exclusively provided to the deserving non-laboring poor: All those of old age, widows, the handicapped, and the chronically ill; at least, when they were fortunate enough to pass the "means test," confirming that they were not receiving support from relatives or other donors. The decision to make poor relief conditional on proper behavior, attach conditions such as workfare under surveillance in poor houses, and add penal sanctions to prevent or at best restrain false claims, was much inspired by the need to show the better-off public that support would only be extended to deserving cases and even then under duress. Access to social assistance was given a coercive twist. As Peter Townsend summarized, the rationale of the Poor Laws amendment was to place the burden of destitution upon the individual and to treat that individual's poverty as simply a question of his or her moral fault. ${ }^{9}$ Those with a right to relief before, able to work but previously acknowledged as being part and parcel of the deserving poor, were reclassified as non-deserving for their incidental failure to find gainful employment. That stigma would last under the by now rapidly expanding regime of capitalism.

The emphasis given to selective assistance-together with the continued refusal to compare conditions of the poor with those of the rich and match their rights - reflected the distrust and lack of acquaintance of

8 De Tocqueville, Memoir on Pauperism, 30.

9 Peter Townsend, "The Right to Social Security and National Development; Lessons from oECD experience for low-income countries," Issues in Social Protection. Discussion Paper No.18, Social Security Department, ILO. (Geneva, 2007). 
leading classes and administrators with the poor that had marked English class attitudes for generations. ${ }^{10}$

The author's observation is no less valid for the manner in which poverty came to be dealt with elsewhere in Europe's past.

The growing reluctance of the non-poor to contribute to a common fund spent on labor labeled as unwilling to search for waged work and thus take care of their own sustenance, seemed to be the immediate ground for the reform of the Poor Laws that was carried through. More hidden sentiments behind expressing annoyance at what was portrayed as a "free riders" mentality were inspired by a steadfast refusal in the drawn-out capitalist transformation to accept maintenance of the idle poor as a burden on the localized commonwealth in which all must share. It was certainly no coincidence that the revisions to the Poor Laws were passed by parliament two years after the Reform Act of $183^{2}$ was approved, which gave suffrage to the middle class. A covertly held consideration of the revision was the widely felt need to drive the landpoor and landless out of their habitat in times of distress. Waiting until their labor power would be in demand again, they had been accustomed to make do with what local relief provided. Thomas Hardy wrote that in the aftermath of the ordinance, agricultural laborers wandered around like birds of passage and trekked to towns and cities in desperate search of a job. ${ }^{11}$ Uprooted from where and how they used to work and live, this reserve army now stood accused of escaping into vagrancy, and of a stubborn unwillingness to resettle in sedentary dependency. In a case study on pauperism in the late-Victorian decades, Elizabeth Hurren discusses how the makeshift economy that arosewith work available off and on or not at all—heightened reliance on public relief. However, under the new amendment, the agrarian poor were cut off from such support to alleviate their immiseration. In the county Hurren focused on, the landless laborers tenaciously and in collective action resisted becoming excluded from what they had fought for as their customary right since the late-medieval centuries. ${ }^{12}$

In Germany, Max Weber's treatise on the agrarian question toward the end of the nineteenth century is of equal relevance for understanding how the social question was handled in rural Europe on the verge of the transition to

\footnotetext{
10 Townsend, The Right to Social Security, 28.

11 Thomas Hardy, "The Dorsetshire Labourer," Longman's Magazine (1883). Republished as The Dorset Farm Labourer: Past and Present (Dorchester, 1884).

12 Elizabeth T. Hurren, Protesting About Pauperism. Poverty, Politics and Poor Relief in LateVictorian England, 1870-1900 (Woodbridge, 2015).
} 
capitalism. Elaborating on the concept of patrimonial rule practiced in the eastern provinces, he characterized the relationship between the landlord (Junker) - who tended to maximize power and status instead of productionand his farm servant, as one of bondage that took the form of a beck-and-call relationship. These servants had previously been attached to their master's household on an annual contract according to which they received discretionary benevolence for the ongoing though erratic use made of their labor power. It was a form of servitude that modified ruthless exploitation with features of patronage.

The master 'owes' the subject something as well, not juridically, but morally. Above all —if only in his own interest—he must protect him against the outside world, and help him in need. He must also treat him 'humanely,' and especially he must restrict the exploitation of his performance to what is 'customary.' On the ground of a domination whose aim is not material enrichment but the fulfillment of the master's own needs, he can do so without prejudicing his own interest because, as his needs cannot expand qualitatively and, on principle, unlimitedly, his demands differ only quantitatively from those of his subjects. And such restriction is positively useful to the master, as not only the security of his domination, but also its results greatly depend on the disposition and mood of the subordinates. The subordinate morally owes the master assistance by all the means available to him. ${ }^{13}$

The Verein für Sozialpolitik (Social Policy Association) took the initiative to launch an inquiry into agrarian labor relations in different parts of the country. In the voluminous questionnaire sent out in 1890, only landowners were addressed-over 3,000 of them-but no data was collected from the farmworkers themselves. Their omission from the investigations was criticized by Weber, who accepted the request to analyze the findings reported for the eastern provinces. ${ }^{14}$ In this first and only empirical research project he handled, he focused his attention on the inroads capitalism had made in the rural economy east of the Elbe river during the previous few decades. A drastic change in the crop pattern caused by a higher volume of international grain trade had led to a pronounced seasonality in the cultivation cycle. In reaction

13 Max Weber, Wirtschaft und Gesellschaft, Grundriss der Sozialökonomik, III Abteilung (Tübingen, 1922), 682.

14 Paul F. Lazarsfeld and Anthony R. Oberschall, "Max Weber and Empirical Social Research," American Sociological Review 30, no. 2 (1965): 185-199. 
to the accelerated pace of commercialization, the estate owners in Prussia had started to replace their servile workforce by free, though casual, labor hired only when their presence was required in the peak periods. Gangs from Poland and Russia- "barbarian hordes" in Weber's vocabulary - with less physical strength, but willing to work on very low wages, flooded the countryside of eastern Germany in the busy months, to disappear again when employment fell. In the migrant worker, the landlord found what he wanted: A commodity. In Weber's view, the seasonal arrival of this floating segment made manifest the class struggle waged in the countryside of eastern Germany.

The migrant worker, torn from his family and usual environment, is regarded as simple labour power both by the landlords and by himself. The barracks of the migrant workers are the money-equivalents of the slave trade barracks of antiquity. The estate owner saves on workers' housing, since accommodation for the migrants costs little or nothing. He also has no need to allocate plots of land, but above all he is not regulated by laws governing conditions of work and pay. Thus while the seasonal wage rates are higher, taken over the year the employer lays out no more, usually less, than he used for a resident worker throughout the year. ${ }^{15}$

Landlords were no longer willing to guarantee the livelihood of their farm servants in the relentless drive for proletarianization. While circulating migrants from far away were hired whenever required, the local landless could not survive on intermittent casual work. They had become superfluous to demand, and took off to the city to find work in industry, construction, transport, or any other sector of the now rapidly expanding and booming urban economy. However, farmhands did not opt out of agrarian employment only to avoid a decline in their living standards. Weber argued that an additional reason for the land flight of the attached farmhands was motivated by a lust for freedom; their craving to get out of personal subservience to a master and his whimsical commands.

\section{How to Deal with Pauperism?}

Dissatisfied with what he had come to know during his first short visit to England, Tocqueville decided to probe more deeply into the causes and impact

15 Max Weber, "Development Tendencies in the Situation of East Elbian Rural Labourers," trans. Keith Tribe, Economy and Society 8, no. 2 (1979): 177-205, here: 193. 
of the ongoing pauperization. He returned in 1835 on a second tour, which brought him to Manchester where the land flight of many people hailing from the countryside in Middle England and Ireland ended. He showed himself to be horrified by what he saw and heard in this brutal heartland of capitalist industrialism, and described in vivid detail the immense squalor of industrial work and life as well as the stark contrast between wealth and misery:

you will see the huge palaces of industry. You will hear the noise of furnaces, the whistle of steam. These vast structures keep air and light out of the human habitation which they dominate; they envelop them in perpetual fog; here is the slave, there is the master; there the wealth of some, here the poverty of most; there the organized efforts of thousands produce, to the profit of one man, what society has not learnt to give. Here the weakness of the individual seems more feeble and helpless even than in the middle of a wilderness; here the effects, there the causes ... From this foul drain the greatest stream of human industry flows out to fertilise the whole world. From this filthy sewer pure gold flows. Here humanity attains its most complete development and its most brutish; here civilization works its miracles, and civilized man is turned back almost into a savage. ${ }^{16}$

His portrait was strikingly similar to the one Friedrich Engels would publish ten years later. ${ }^{17}$ Pauperism was the inevitable outcome of this hellish kind of industrialism, and the by now well-known author tersely commented that the condition of the poor was nowhere as abysmal as in England. His judgement was that the laboring poor had become entrapped in a new form of servitude. From his sojourn in industrial England, Tocqueville journeyed on to agrarian Ireland where in July and August 1835 he took stock of the disastrous impact the enclosure movement had on the dispossessed victims. From his coachthe seasoned traveler carefully abstained from coming too close to the scene of pauperism-Tocqueville glimpsed the hand-to-mouth existence he came across. The subhuman standard to which the Irish peasantry had sunk preceded the Great Famine that broke out barely ten years later, leading to the death of about one million Irish, while another million left home to emigrate. In the ensuing havoc, the country lost a fifth to a quarter of its population.

16 Alexis de Tocqueville, Journeys to England and Ireland, ed. J.P. Mayer (Forge Village, MA, 1958), 107-108.

17 Friedrich Engels, The Condition of the Working Class in England in 1844, trans. F.K. Wischnewetzky (New York, 1887). 
In his first Memoir on Pauperism, the aristocrat had spoken out in favor of private charity to alleviate poverty, arguing that personalized transfers strengthened the moral bond between donors and recipients. While voluntary gifts contributed to social harmony, he posited that public relief was disgruntledly given as well as received. Its effect was to raise resentment on both sides, and would instigate a class struggle erupting in revolution. ${ }^{18}$ Tocqueville had second thoughts, however, when confronted on his second tour with the abominable plight of the workforce in the "satanic mills" in Manchester, and in Ireland, with the callous behavior of the estate owner who could not care less about the destitution of the tenants chased off by him.

He will take walks in immense grounds surrounded by high walls. Within his park everything breathes splendor; outside misery groans, but he does not notice it. His doormen take care to keep the poor from his sight and if by accident he meets one, he answers his entreaties by saying, 'I make it a duty not to encourage begging.' He has big, fat dogs, and his fellows die at his door. Not only do they not help the poor in any way, but they profit from their needs by charging enormous rents which they spend in France or Italy. If for a short time one returns among us, it is only to evict a farmer who is behind with the rent and chase him from his home. ${ }^{19}$

When asking one of his high-class informants about agrarian relationships in the country's past, Tocqueville was given to understand that the peasants also hated their landlords then. However, they used to submit to their ordeal with a patience they had since lost. The problem arose, he was told, from the destruction of the moral tie between rich and poor, who had come to live far apart from each other. He ended his second tour to England and Ireland convinced of the devastating impact the new and spreading mode of production was having in urban as well as rural settings.

What about private charity to solve what the social question is all about? On his initial confrontation with widespread destitution, Tocqueville had no doubt that this was a better alternative to public relief. Today's neoconservative apostles of market fundamentalism could not agree more with the stance taken by him, which is why his first Memoir on Pauperism surfaced again in 1997. Long ignored in Tocqueville's body of work, the conservative think tank Civitas released it on their website for dissemination free of charge. The reprint from the original edition was augmented with an introduction by

18 De Tocqueville, Memoir on Pauperism, 17.

19 De Tocqueville, Journeys to England and Ireland, 165. 
Gertrude Himmelfarb, a stalwart of the American caucus spreading the reactionary dogma of market fundamentalism. In her comments, she stresses not only the vices of the paupers, then as well as now, but also "the undue degree of state control and centralization" to which mandatory public welfarism gives rise. ${ }^{20}$ This historian's main attention is clearly focused on the social question in today's global order and, of course, all forms of public action or agency - from the New Deal in the United States to the welfare state in Britain and Europe - are anathema to her. In the neoconservative scenario, the poor and paupers are bid welcome to join the better-off in the race to accumulation and are then lambasted for their failure to do so. Tocqueville's unequivocal condemnation of public welfare explains why the Institute for the Study of Civic Society decided to republish Memoir on Pauperism as a Rediscovered Riches publication. Its renowned author was praised not only for his objection to the way in which the undeserving poor were pampered out of the common fund, but also for his critique of the government machinery set up to cater to the needs of this underclass clientele. He minced no words in taking these public officials to task, and it comes as no surprise that his scornful exposure of the costly, bossy, but useless bunch of officials in charge of public relief is much appreciated by today's anti-state cabal. Its proponents are clamoring for the empowerment of civic society, by which they mean something quite different from the usual brand of non-government organizations that advocate all forms of welfare interventions. While such agencies advocate on behalf of people whose voice is not heard and whose interests are not served, the former are neoconservative apostles of a civic society preaching the gospel of individual freedom. Their main objective behind the virtuous façade is not to upset the excessively skewed distribution of wealth and privilege.

Tocqueville decided on a more in-depth study of the problem of pauperism, which was very much en vogue and debated in Great Britain, and had already returned two years after his first visit for a second tour. Taking stock of what was going on, which included consulting policymakers and front-rank figures, led him to a fundamentally different opinion. As in England, Tocqueville did not trouble himself to meet with the outcasts when touring around Ireland, but put on record what he found out about their plight by keeping the company of the upper-class authorized to know. In his interview with the bishop of Carlow, he learned that the land in this county was basically the property of two families. The new system of cultivation that had been introduced meant the end of smallholdings parceled out in a tenancy relationship. One of the landowners had evicted 150 families. The bishop's colleague in Kilkenny told

20 Gertrude Himmelfarb, "Introduction," in De Tocqueville's Memoir on Pauperism, 1-16. 
his guest a similar story. All the arable land had been turned into grassland, so that 10 shepherds were now enough where there had previously been 150 laborers. The dispossession, which had already been going on for decades, ended in wide-scale impoverishment and the absence of public relief in Ireland, and to the starvation of the people. Was the gist of his much more nuanced reappraisal dealt with fairly and fully in the introductory commentary of the 1997 edition of his Memoir? Not really, and I fully agree with other critics who have taken Himmelfarb to task for having misreported the author's thoughts on how to tackle the social question (see for example Keslassy and Cruikshank). ${ }^{21}$ In summarizing Tocqueville's stance, the current brand of neoconservative historians have grossly understated both his incisive-though low-keyadmonitions of capitalism, and his firm stance that the privileged rich to a large extent bear responsibility for the adversity of the poor. Tocqueville's sociological imagination induced him to highlight pauperism as the outcome of a civilizational trend toward increasing inequality in the transition from an agrarian-rural to an urban-industrial way of life. In his opinion, dispossession was a major reason for the growing social divide. That verdict, already reached in the early stage of capitalist development, has with its spread over the global economy become more topical and relevant than ever before.

The transition from an agrarian to an industrial mode of production played an important role in Tocqueville's understanding of why, when, and how pauperism came about. The gap between the rich and the poor grew wider, because the class at the top developed new tastes, which in order to be satisfied, required the production of manufactured commodities. The gratification of what became an insatiable penchant for consumerism triggered a more diversified system of production. These dynamics led to a restructuring of the workforce, which meant that "men left the plow for the shuttle and the hammer; they moved from the thatched cottage to the factory."22 The industrial economy that emerged made the working classes more vulnerable, since it increased their dependency on market forces over which they had no control. This was due to fluctuating demand ending in job loss or displacement when artisanal skills became outdated and replaced by new crafts and wares. The industrial class, which gives so much impetus to the well-being of others, is thus much more exposed to sudden and irremediable evils, Tocqueville surmised, with

21 Barbara Cruikshank, “Tocqueville's Authority: Feminism and Reform 'Between Government and Civil Society," in Feminist Interpretations of Alexis de Tocqueville, eds. J. Locke and E.H. Bunting (State College, PE, 2009), 305-335; Eric Keslassy, Le Libéralisme de Tocqueville à l'épreuve du Paupérisme (Paris, 2000). 
the paradoxical consequence that "the richer a nation is, the more the number of those who appeal to public charity must multiply." ${ }^{23}$ So what should be done to enable the victims of destitution to live up to their human condition? With keen insight, Tocqueville observed that the needs of the impoverished are elastic and cannot be fixed and kept constant at a minimum level that is indispensable for sheer survival. The class in destitution is prone to emulate the lifestyle of the non-poor, and what used to be the desires of yesteryear for elite comfort is bound to change over time into habits which shortly also become daily necessities for those at the bottom of the pile. Tocqueville formulated what in sociological jargon is known as the phenomenon of relative deprivation, which suggests that who you are and what you do not have, but want, should be seen in the wider frame of inter-class relationships. The basic message his memoir conveys is that prosperity and pauperism are interdependent and have to be contextualized in the total social fabric. Having initially rejected public relief as an ineffective or even counterproductive palliative, Tocqueville was more positive about private charity, which encourages individual transfers from the well-to-do to the impoverished. On the other hand, at the end of his first tour he had already conceded that this discretionary remedy cannot be relied upon, does not deliver timely or adequately when and where required, and is "not aroused by every cry of pain." Having weighed both options, the author's starting point in his consideration of welfare provisioning is that the poor have an absolute and pre-emptive right to help from society in coping with their misfortune.

\section{Redistribution}

If pauperism cannot be redressed by either public or private welfare, what other course of action then remains to solve the social question? This was the query that brought Tocqueville back for his second visit to Great Britain. The findings resulting from his travel to industrial England and agrarian Ireland did not appear in print straightaway, and this is why the latter-day proponents of neoconservative policies are apt to conclude that Tocqueville's treatise on pauperism remained a project that he failed to finish. This is a misconceived assessment, underrating the importance of the manuscript that the author did produce but never published. As Himmelfarb states, "because the problem of industrial pauperism seemed to him intractable." She follows up this erroneous judgement with the lament that the second essay lacks the sweep 
and passion of the first one. Once again, this interlocutor's final conclusion is out of tune with Tocqueville's recommendations. Her complaint is his failure to apprehend the potentialities of industrialism to improve the condition of the poor without recourse to charity; private or public. The author, so highly praised for what he condemned - the moral hazards of public welfarismnow stands accused for his stubborn refusal to profess unconditional faith in the virtues and blessings of capitalism. The same disappointment is expressed more forcefully in the foreword by Max Hartwell to the 1997 edition of the first memoir:

Tocqueville, however, did not foresee that economic growth, largely the consequence of private enterprise, would raise all living standards, and that continuing private charity would help to alleviate hardship. He clearly recognized the moral hazard of public welfare, but too easily accepted that its consequence was universal degradation. He did anticipate, however, the problems of the welfare state that are still with us. ${ }^{24}$

The criticism expressed was directed at Tocqueville's opinion that the growing disparity in the world at large-further enrichment at the top and steady impoverishment below - could only be halted and reversed by a fundamental reallocation of what produces welfare and well-being for all. To start with, redistribution of land was the forceful recipe he prescribed for redressing immiseration in the English and Irish countryside. In the same vein was his proposal to encourage industrial laborers to have a stake in the enterprises in which they work, to create space for voluntary associations along both vertical and horizontal lines of collaboration, to establish workshops on their own, and to set up savings banks funded with contributions out of the wealth generated by industrial production. While Tocqueville was skeptical about the short-term viability of initiatives taken on the basis of collective action from below, he predicted that in due course, with increased exposure to education and growing tolerance for workers' cooperatives, impediments to self-management could be overcome. This remedy of worker's emancipation-essentially a plea in favor of small-scale manufacture and commodity production in partnership-is glossed over rather than discussed by today's critics of public agency and by institutions who keep hammering on the immorality of pauperism. No doubt, this is not the sweep and passion which Himmelfarb wants to find back in Tocqueville's writings, but that is because in her ideological lexicon, enrichment and impoverishment should not be seen as progressing in tandem, but as 
contrasts that testify to a behavioral divide deserving respectively praise versus blame. In a scathing review, Michael Katz has shown how in the late-twentieth century, reactionary voices came to dominate the debate on poverty in America and why, in the prevailing policies and politics, a regime of welfare grounded in equality as the organizing principle of the social fabric was jettisoned. ${ }^{25}$

Did Tocqueville's reservations and warnings of the dangers of a looming class conflict, discussed at length in his notebooks as well as in the manuscript of his second memoir, show him to be adverse to capitalism? Not at all, because the question he raised was how to imbibe the paupers with the accumulative instinct on which the spirit of capitalism is founded. Redistribution of property was his plain and straightforward solution; a remedy that he specified by pointing out the imperative need for land reforms to mitigate the impact of agrarian dispossession, and thus prevent the exodus from the countryside of a proletarianized class in desperate search of regular work and income. My reading of his work, the first and second memoirs, leads me to conclude that Tocqueville rested his case and gave up writing about the social question. Not because he had failed to find a solution to the problem, but because the policy of redistribution, which he proposed for redressing pauperism, was rejected out of hand by the powers that be. He reported on wage levels going down rather than up, and on the substitution of women and children for men in the Manchester mills because they were cheaper to employ as well as easier to exploit. In his second memoir, Tocqueville placed in the foreground that accumulation and sharing should be seen as complementary and not contradictory. The inequality that he found in his travels around Britain frightened him, and the reforms he advocated aimed to defuse the widening gap between poverty and prosperity as well as to reduce the increase in distance between the classes at the top and bottom of society. At the end of his first visit to England he had already expressed his amazement about land concentration in the hands of a small aristocratic elite leading to a ceaseless growth of the proletarian class:

"The English are still imbued with that doctrine, which is at least debatable, that great properties are necessary for the improvement of agriculture, and they still seem convinced that extreme inequality of wealth is the natural order of things." 26

Of course, redistribution of property - rural and urban as well as agrarian and industrial — as the way out of the dilemma fell on deaf ears, and this was why he quit. Was his soft-spoken warning heeded later on? What Tocqueville

\footnotetext{
25 Michael B. Katz, The Undeserving Poor: America's Enduring Confrontation With Poverty (New York, 2013), second and revised edition, 156-202.

26 De Tocqueville, Journeys to England and Ireland, 72.
} 
diagnosed as a broken moral bond, an alliance of trust between elite and underdogs that he projected back to a rustic past, has failed to be repaired. The nascent capitalism that Tocqueville found in Great Britain in 1835 would become the dominant mode of production in the world at large. The crux of his analysis is that accumulation and sharing must expand hand in hand, while in reality the former has tended to increase at the cost of the latter. Tocqueville realized that he had reached a dead end; the steadfast refusal of the owners of capital to compromise on their accumulative drive when that also implied the denial of stakes held in the lower echelons of the economy. It happens to be an unwillingness regimenting the capitalist mode of existence in the past and the present. 